\title{
REPRODUCTION OF COD, GADUS MORHUA (ACTINOPTERYGII: GADIFORMES: GADIDAE), FROM THE GDAŃSK DEEP (BALTIC SEA) UNDER CONTROLLED CONDITIONS
}

\author{
Marcin BIERNACZYK ${ }^{1 *}$, Zbigniew NEJA ${ }^{1}$, Artur OPANOWSKI ${ }^{1}$, Katarzyna STEPANOWSKA ${ }^{1}$, \\ Krzysztof FORMICKI ${ }^{2}$, and Wawrzyniec WAWRZYNIAK ${ }^{3}$
}

Faculty of Food Sciences and Fisheries, West Pomeranian University of Technology, Szczecin, Poland

${ }^{1}$ Division of Hydrochemistry and Aquatic Biological Resources

${ }^{2}$ Division of Hydrobiology, Ichthyology and Biotechnology of Reproduction

${ }^{3}$ Division of Fisheries Management,

\begin{abstract}
Biernaczyk M., Neja Z., Opanowski A., Stepanowska K., Formicki K., Wawrzyniak W. 2016. Reproduction of cod, Gadus morhua (Actinopterygii: Gadiformes: Gadidae), from the Gdańsk Deep (Baltic Sea) under controlled conditions. Acta Ichthyol. Piscat. 46 (3): 239-246.
\end{abstract}

Background. The stocks of cod, Gadus morhua Linnaeus, 1758, have been declining within recent decades and the Baltic Sea is one of the most affected areas. The latter body of water with its low salinity, pollution, and vast areas of demersal hypoxia is particularly vulnerable. Areas of natural spawning are scarce and the reproductive output of cod has been irregular and more and more limited. One of the proposed solutions for this problem might be an artificial reproduction. One of such areas has been the Gdańsk Deep, but the number of potential brood fish is relatively low, which makes the eggs and sperm poorly accessible. The aim of the presently reported study was to conduct spawning and egg incubation under controlled conditions to obtain viable hatchlings and to monitor the embryonic development of cod originating from the area of the Gdańsk Deep.

Materials and methods. The parental fish specimens were obtained during commercial trawl catches. The eggs were fertilized artificially at the field laboratory using filtered brackish sea water with salinity of $15 \%$, and then were incubated at a constant temperature of $8 \pm 0.5^{\circ} \mathrm{C}$. Eggs and larvae development, and larvae beginning exogenous feeding were observed under a stereo microscope, and photographed regularly to determine the sizes of the eggs and larvae and to document the results of the experiment.

Results. The mean percentage of fertilization of eggs was $70 \%$. Hatching began $236 \mathrm{~h}$ after fertilization, and the newly hatched larvae comprised $30 \%$ of the initial stocking density. The mean length of the larvae was $3.95 \mathrm{~mm}$. The cod larvae began exogenous feeding before the yolk sac was fully absorbed.

Conclusion. Artificial reproduction with gametes obtained from cod spawning in the Gdańsk Deep is possible, and the fertilization rates obtained were similar to those achieved with cod from the Bornholm and Gotland basins. Therefore, our results also show that cod spawning in the Gdańsk Deep can be suggested as a model species for further research.

Keywords: Baltic Sea, embryogenesis, eastern Baltic cod, artificial reproduction

\section{INTRODUCTION}

Atlantic cod, Gadus morhua Linnaeus, 1758, fisheries have for centuries been important to the economies of Europe and North America (Garrod and Schumacher 1994, Lear 1998). Today cod is one of the most valuable fish species caught in the North Atlantic, thanks to its nutritional and organoleptic properties. In Poland it is the most economically important species in the Baltic fisheries (Radtke 2003, Horbowy 2009). Heavy fishing pressure and environmental changes have led to drastic decreases in the biomass of the majority of cod spawning stocks in the late 1980s and early 1990s that resulted in distinct declines in catches (Myers et al. 1996, Brander 2005, Köster et al. 2005, Anonymous 2006). Total cod catches, which were nearly 4 million tons in 1970, did not even reach one million tons in 2000 (Anonymous 2006).

The causes of declining cod catches in the Baltic were probably more complex than they were in other bodies of water in its range, because of the specific hydrological characteristics of this sea. The Baltic is a brackish sea

\footnotetext{
* Correspondence: Dr Marcin Biernaczyk, Zakład Hydrochemii i Biologicznych Zasobów Wód, Wydział Nauk o Żywności i Rybactwa, Zachodniopomorski Uniwersytet Technologiczny w Szczecinie, ul. Kazimierza Królewicza 4, 71-550 Szczecin, Poland, phone: +48 91-449-66-83, fax: +48 91-449-66-54, e-mail: (MB) marcin.biernaczyk@zut.edu.pl, (ZN) zbigniew.neja@zut.edu.pl, (AO) krolartur@poczta.fm, (KS) greyseal@o2.pl, (KF) krzysztof.formicki@zut.edu.pl, (WW) wawrzyniec.wawrzyniak@zut.edu.pl.
} 
with a salinity that varies spatially both vertically and horizontally. In the southern and central parts of the sea (ICES Subdivisions 25-28), the salinity of the nearsurface layer above the halocline at the depth of $45-80 \mathrm{~m}$ is $6 \%{ }_{0}-8 \%{ }^{*}$. In the near-bottom layer beneath the halocline, salinity is more variable and ranges from $10 \%$ to $18 \%$, and when the depth of the halocline increases, salinity in both of these layers decreases toward the east. Cod eggs require a minimum salinity of about $12 \%$ in order to maintain neutral buoyancy (Nissling and Westin 1991, Nissling et al. 1994, Vallin and Nissling 2000), which prevents them from sinking into deeper water layers where oxygen deficits often occur. Additionally, lower salinity distinctly decreases in the percentage of fertilized eggs (Westin and Nissling 1991). This means that effective cod spawning in the Baltic can only occur in the Bornholm-, Gdańsk-, and Gotland deeps. Salinity in the waters beneath the halocline is not stable, and it is determined largely by inflows of saline waters from the North Sea that occur irregularly and are of various volumes (Meier and Kauker 2003, Mohrholz et al. 2015). The periodic lack of inflows or those of insufficient volume not only result in decreased salinity in the deepest layers of the Baltic deeps, but they also lead to the gradual depletion of oxygen in these layers, which are the only locations in the Baltic that are suitable for cod spawning.

Other fundamental factors determining reproductive success of cod, Gadus morhua, in the Baltic Sea are: availability food suitable for cod larvae (Hinrichsen et al. 2003, Brander 2005), predator pressure on cod eggs and larvae (Köster and Schnack 1994, Köster and Möllmann 2000, Neuenfeldt and Köster 2000, Uzars and Plikshs 2000, Wieland et al. 2000), the degree of cannibalism with regard to the eggs that varies depending on geographic location, total cod abundance, and the concentration of juveniles (Köster et al. 2003), and the hydrographic conditions (Uzars and Plikshs 2000). Accordingly, cod management cannot be limited only to the regulation of the fisheries, and two new approaches to managing cod resources should be implemented alongside traditional methods. The first is a holistic management approach that takes into consideration both the ecological and economic consequences of management (Lindegren et al. 2009), and the second is to include an aquaculture-based fishery (Rosenthal and Hilge 2006, Støttrup et al. 2008).

Producing stocking material of fish species that are economically important is one way aquaculture can support and contribute to sustainable fisheries. Spawning conducted under controlled conditions also permits garnering a better understanding of the biology of a given species and allows producing fish that can be used as a model species in a variety of physiological, feeding, or rearing studies. In Poland, one such species has long been common carp, Cyprinus carpio Linnaeus, 1758, a freshwater fish, but it is advisable that cod also be produced under controlled conditions as it could be a model species in various types of studies in marine waters at the different stages of its development.
This is especially important with regard to the Baltic cod, Gadus morhua, especially those spawning in the Gdańsk Deep, because the reproduction and development of this species are impacted by many disparate factors, about some of which little is known. This refers especially to mutual relations pertaining to cod spawning and development, which are the types of study that can only be performed in the laboratory. It is also noteworthy that the irregularity of cod spawning in the Gdańsk Deep that is caused by the lack of suitable conditions in the spawning layer (Grauman 1973, Nissling et al. 1994), and recently most likely by its rarity, makes it difficult, or even impossible, to obtain viable eggs and larvae with which the studies mentioned above can be conducted. On the other hand, the ability to conduct the cod spawning coming from Gdańsk Deep in the laboratory conditions, and then the opportunity to study its biology, in various stages of development may have cognitive significance in the context of disturbing observations of cod from the southern Baltic Sea (potential spawning groundGdańsk Deep) on decline in cod condition (very low Fulton's condition coefficient) and the growth rate in terms of length-at-age has also declined (Anonymous 2015).

The aim of the study was to conduct spawning and egg incubation under controlled conditions to obtain viable hatchlings and to follow the embryonic development of cod that spawn in the area of the Gdańsk Deep.

\section{MATERIALS AND METHODS}

The study was conducted in a sea resort, Jastarnia, in a field laboratory in June 2009. The study material was obtained from commercial trawl catches done in the southwestern part of the Gdańsk Deep (fishing area- $54^{\circ} 45^{\prime} \mathrm{N}-$ $18^{\circ} 45^{\prime} \mathrm{E} ; 54^{\circ} 45^{\prime} \mathrm{N}-18^{\circ} 55^{\prime} \mathrm{E} ; 54^{\circ} 55^{\prime} \mathrm{N}-18^{\circ} 40^{\prime} \mathrm{E} ; 54^{\circ} 55^{\prime} \mathrm{N}-$ $\left.18^{\circ} 50^{\prime} \mathrm{E}\right)$. The cod were caught at a depth of about $90 \mathrm{~m}$ with a Bakoma benthic trawl.

Experimental artificial spawning was performed using eggs obtained from five live females in the VI and VII stages of maturity according to Maier's scale (Laevastu 1965). Sperm was also collected from five live males. The eggs and the sperm were kept in a $500 \mathrm{~mL}$ thermos at $5^{\circ} \mathrm{C}$. The sperm and eggs were collected by gentle hand stripping, and they were not contaminated with blood, faeces, or urine. The gametes were transported within 5 $\mathrm{h}$ to the field laboratory, where the eggs were artificially fertilized in filtered marine water of a constant salinity of $15 \%$ maintained throughout the entire incubation period. After the eggs had swelled, they were divided at random and moved into three $1.5 \mathrm{~L}$ tanks with intensive bottom aeration, forcing continuous water and spawn movement.

The experiment was carried out in an isothermal room at $8 \pm 0.5^{\circ} \mathrm{C}$. Half of the water volume was exchanged daily, maintaining the temperature and salinity regime, and dead eggs were removed from the bottom after a $2 \mathrm{~min}$ shutdown of aeration. An ECOVISION stereomicroscope was used to observe the developing eggs, and photographic documentation was taken throughout with a Nikon D60 camera. 
The sizes of the eggs and larvae were determined from photographs taken against a $1 \mathrm{~mm}$ measurement grid background. The images were processed with a computer, and the percentage of fertilized eggs and hatch were estimated with the volumetric method.

\section{RESULTS}

The mean diameter of the incubated cod eggs was 1.77 $\mathrm{mm}$, and the mean length of the larvae obtained was 3.95 $\mathrm{mm}$ (Table 1). The mean percentage of fertilization in the three tanks was $70 \%$, and larvae comprised $30 \%$ of the initial stocking density of the tanks.

The developmental process of eggs, larvae, and larvae beginning exogenous feeding (fry) is presented below with photographic documentation of the changes that occurred (Figs. 1-3). Larvae are presented in Fig. 3D, and feeding fry in Fig. 3E.

Photographic documentation of embryonic development beginning $12 \mathrm{~h}$ after fertilization:

- $12 \mathrm{~h}$ after fertilization-embryonic development at the fifth cleavage (32 blastomeres) (Fig. 1A);

- $20 \mathrm{~h}$ after fertilization-8 $\mathrm{h}$ after observations began, the number of germinal layers increased and the eggs entered the blastula stage (Fig. 1B);

- $32 \mathrm{~h}$ after fertilization-cells began to move to the outside of the embryo germ layers and overgrew the interior of the egg (early gastrula) (Fig. 1C);

- $55 \mathrm{~h}$ after fertilization - the primitive streak formed in the developing eggs (Fig. 1D);

- 79-80 h after fertilization-24 h after the beginning of the formation of the primitive streak, it began to form the embryo body (Fig. 2A);

- $88 \mathrm{~h}$ after fertilization-the anterior embryo body section was formed and was clearly visible (Fig. 2B);

- $110 \mathrm{~h}$ after fertilization-myomeres and melanophores were visible, eye lenses began to form in the eye balls, and the blastopore remained open (Fig. 2C);

- $134 \mathrm{~h}$ after fertilization - the lenses were clearly visible, and the blastopore was closed (Fig. 2D);

- $176 \mathrm{~h}$ after fertilization - the primordial fin folds were visible (Fig. 3A);

- $207 \mathrm{~h}$ after fertilization-contractions of the heart muscle and first embryo movements in the egg were clearly visible (Fig. 3B);

- $222 \mathrm{~h}$ after fertilization - the embryos were moving very actively (Fig. 3C);

- $236 \mathrm{~h}$ after fertilization - hatching began (Fig. 3D);

Cod larvae began exogenous feeding before the yolk sac was fully resorbed (Fig. 3E).

\section{DISCUSSION}

The size of fish eggs is significant for their survival rate in the natural environment of the Baltic Sea, and according to Grauman (1973) larger eggs are of superior quality with a higher lipid content that makes them more buoyant allowing them to remain under optimal conditions in the water column farther from the bottom. This is why the survival rate of the larger eggs is higher than that of smaller ones. Grauman's (1973) observations were confirmed under laboratory conditions by Vallin and Nissling (2000), who determined that larger eggs from larger females were neutrally buoyant at lower water salinity. The size of cod eggs from the Gdańsk Deep $($ mean $=1.77 \mathrm{~mm})$ did not differ from the eggs (mean $=1.76 \mathrm{~mm}$ ) of cod caught to the north of Gotland in 1990 (Nissling and Westin 1991). Later studies in the Gotland region (Nissling et al. 1994) conducted within 1990-1993, indicated, however, that the mean size of Baltic cod eggs could be slightly smaller $(1.66 \mathrm{~mm})$. The eggs obtained from female cod from ICES Subdivisions 25-28 in 1993-1997 were also smaller in diameter (mean $=1.62 \mathrm{~mm}$ ) (Vallin and Nissling 2000). However, in comparison to Atlantic cod caught off of the southern coast of Norway-the eggs of which measured from 1.40 to $1.46 \mathrm{~mm}$ in diameter (Ellertsen et al. 1981) cod eggs from the Gdańsk Deep, as might be anticipated, were distinctly larger. We interpret this phenomenon as a buoyancy adaptation to the lower salinity in the Baltic Sea. Consequently, it is evident that the quality of cod eggs from the Gdańsk Deep (presently reported study) were at least comparable, if not better, than those collected from females from the Gotland Deep region and farther south to the Bornholm Deep.

As it was demonstrated by Nissling (2004), the length of newly hatched Baltic cod larvae is in reverse proportion to the water temperature. This relation is not noted within the temperature range of 3 to $9^{\circ} \mathrm{C}$. Based on the incubation temperature of cod eggs in the vicinity of the Gdańsk Deep $\left(8^{\circ} \mathrm{C}\right)$, one can conclude that immediately following hatching these larvae (mean length $3.95 \mathrm{~mm}$ ) were larger than those from the Gotland Deep (mean length 3.72-3.73 $\mathrm{mm}$ ) that were in a water temperature range of $3-9^{\circ} \mathrm{C}$ (Nissling 2004).

The percentage of fertilized eggs $(70 \%)$ obtained in this experiment was relatively low, even though artificial fertilization was conducted in water with a salinity of 15\%. Westin and Nissling (1991) performed artificial fertilization of cod eggs at a salinity range from $5 \%$ to $30 \%$, and as many as $99 \%-100 \%$ of the eggs were fertilized within the salinity range of $12 \%-30 \%$. Clearly

Table 1

Size of eggs and larvae hatched from these eggs of cod, Gadus morhua, from the Gdańsk Deep

\begin{tabular}{lccccccc}
\hline \multirow{2}{*}{ Stage } & $n$ & \multicolumn{9}{c}{ Size $[\mathrm{mm}]$} \\
\cline { 3 - 8 } & & Mean & Confidence interval & Minimum & Maximum & SD & SE \\
\hline Eggs & 35 & 1.77 & $1.70-1.82$ & 1.48 & 2.04 & 0.15 & 0.026 \\
Larvae & 30 & 3.95 & $3.81-4.10$ & 3.13 & 4.66 & 0.38 & 0.069 \\
\hline
\end{tabular}

$n=$ number, $\mathrm{SD}=$ standard deviation, $\mathrm{SE}=$ standard error of the mean. 
lower fertilization rates were noted at a mean of $35.8 \%$ when the salinity decreased to $10 \%-11 \%$, while the percentage share of eggs fertilized dropped to just $9 \%$ when salinity was $10 \%$ o (Westin and Nissling 1991). However, in these studies the sperm used to fertilize the eggs was selected (only those moving fast at 20\%o salinity), and this certainly had a significant impact on the percentage of fertilized eggs. Additionally, another cause of the low fertilization rates of eggs from the Gdańsk Deep could have been the extended transport time of the gametes to the laboratory, because fish sperm motility decreases as storage times lengthen, and this has a negative impact on egg fertilization rates (Formicki et. al. 2013).

Nissling's (2004) studies demonstrated that the optimal temperature for Baltic cod egg incubation is within the range of $3-9^{\circ} \mathrm{C}$, and that within this range
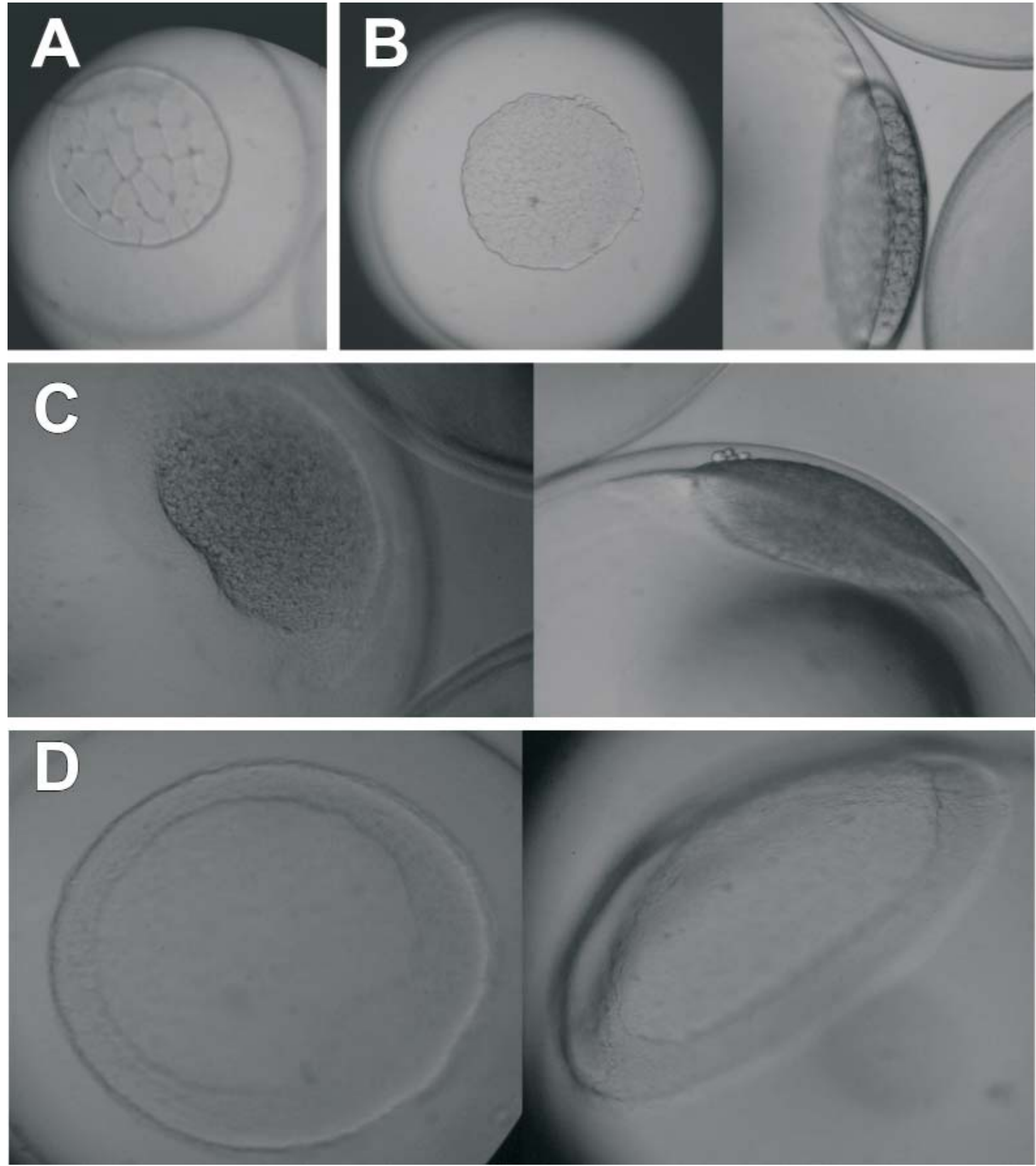

Fig. 1. Eggs of cod, Gadus morhua: $12 \mathrm{~h}$ after fertilization — embryonic development at the fifth cleavage (32 blastomeres) (A); $20 \mathrm{~h}$ after fertilization $-8 \mathrm{~h}$ after observations began, the number of germinal layers increases and the eggs enter the blastula stage (B); $32 \mathrm{~h}$ after fertilization - cells begin to move to the outside of the embryo germ layers and overgrow the interior of the egg (early gastrula) (C); $55 \mathrm{~h}$ after fertilization - the primitive streak forms in the developing eggs (D) 
the survival rate of artificially fertilized eggs from stage IA (Thompson and Riley 1981) to viable hatch exceeds $50 \%$. Wieland et al. (1994) reported lower survival rates for Baltic cod eggs incubated under controlled conditions, but they were similar to those obtained in the presently reported study. When Wieland et al. (1994) incubated eggs at temperatures of $5.0-5.7^{\circ} \mathrm{C}$ and the oxygen content of the water exceeded $5 \mathrm{~mL} \cdot \mathrm{L}^{-1}$, the survival of the eggs to hatch was $22 \%-37 \%$.

Thompson and Riley (1981) described six development stages of cod eggs from the North Sea, and determined the regression coefficients between egg incubation temperatures under controlled conditions and the logarithm of the natural period of time that elapses from fertilization to the end of subsequent stages. Using the coefficients reported by these authors, it was established that, at a temperature of $8^{\circ} \mathrm{C}$, the eggs of cod caught in the vicinity of the Gdańsk Deep developed faster than did cod eggs from the North Sea. It is true that the ends of the first two stages (IA and IB) occurred more quickly in the eggs from the North Sea, but the Baltic cod completed the last stages more quickly. The greatest difference in egg development speed in the two comparable populations was in the moment the hatching began. Cod eggs from the Gdańsk Deep did not even reach stage $\mathrm{V}$, and hatching began 9.8 days following fertilization when the eggs were still in stage IV. Among the North Sea cod, stage IV ended 10.6 days after fertilization, while the end of stage $\mathrm{V}$ and the beginning of hatching did not begin until

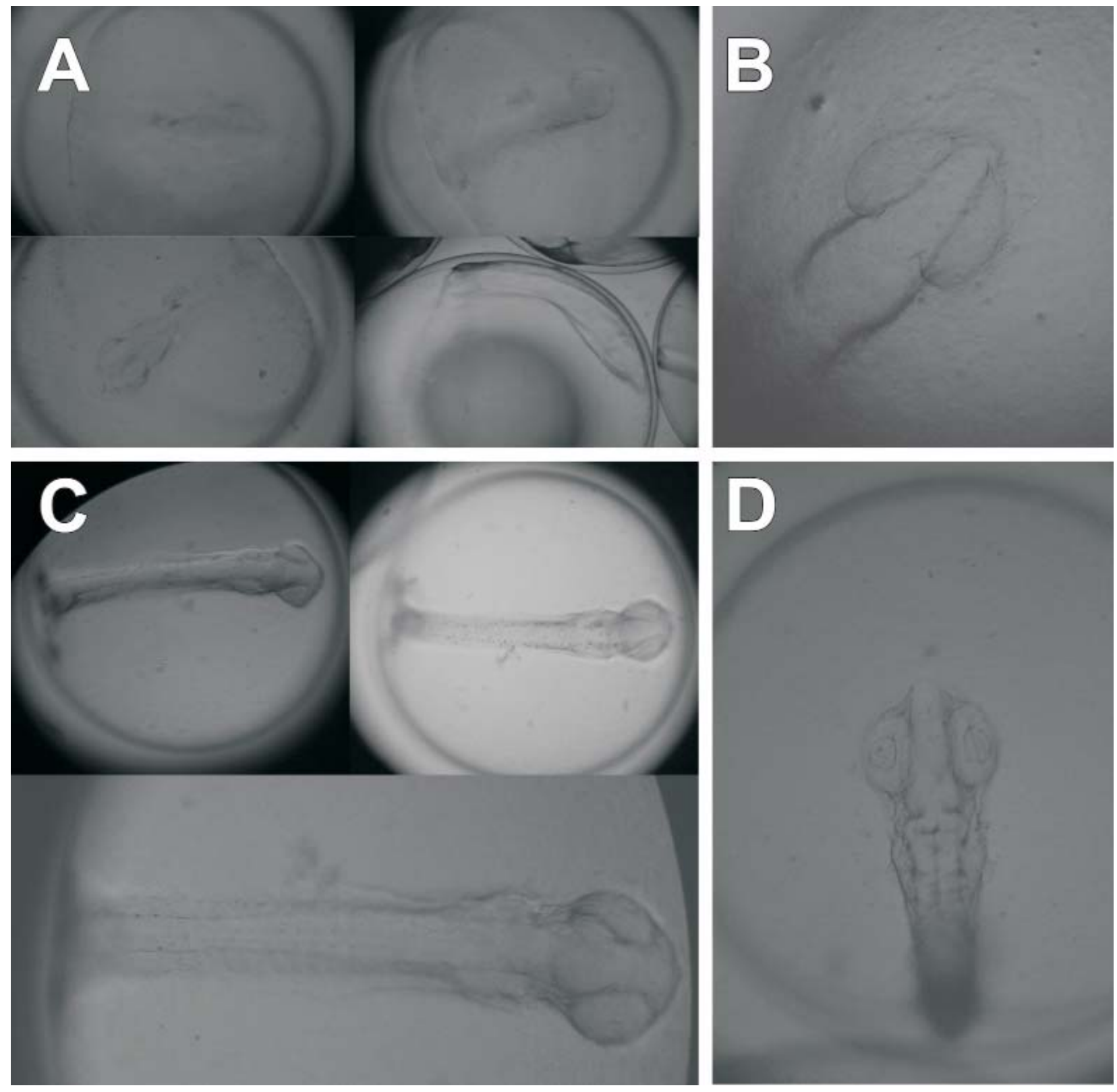

Fig. 2. Eggs of cod, Gadus morhua: $79-80 \mathrm{~h}$ after fertilization $-24 \mathrm{~h}$ after the beginning of the formation of the primitive streak, it begins to form into the embryo body (A); $88 \mathrm{~h}$ after fertilization-the anterior embryo body section is formed and is clearly visible (B); $110 \mathrm{~h}$ after fertilization - miomers and melanophores are visible, eye lenses begin to form in the eye balls, and the blastopore remains open $(\mathbf{C}) ; 134 \mathrm{~h}$ after fertilization - the lenses are clearly visible, and the blastopore is closed (D) 
14.3 days following fertilization. The shorter development period needed by cod in the Gdańsk Deep could stem from the lower water salinity during egg incubation.

The points discussed above provide evidence that cod caught in the spawning grounds in the proximity of the Gdańsk Deep can be used for artificial fertilization and incubation under controlled conditions with a similar success level as was achieved with cod caught in the Bornholm and Gotland basins.

\section{REFERENCES}

Anonymous 2006. Report of the Workshop on the Decline and Recovery of cod Stocks throughout the North Atlantic, including tropho-dynamic effects
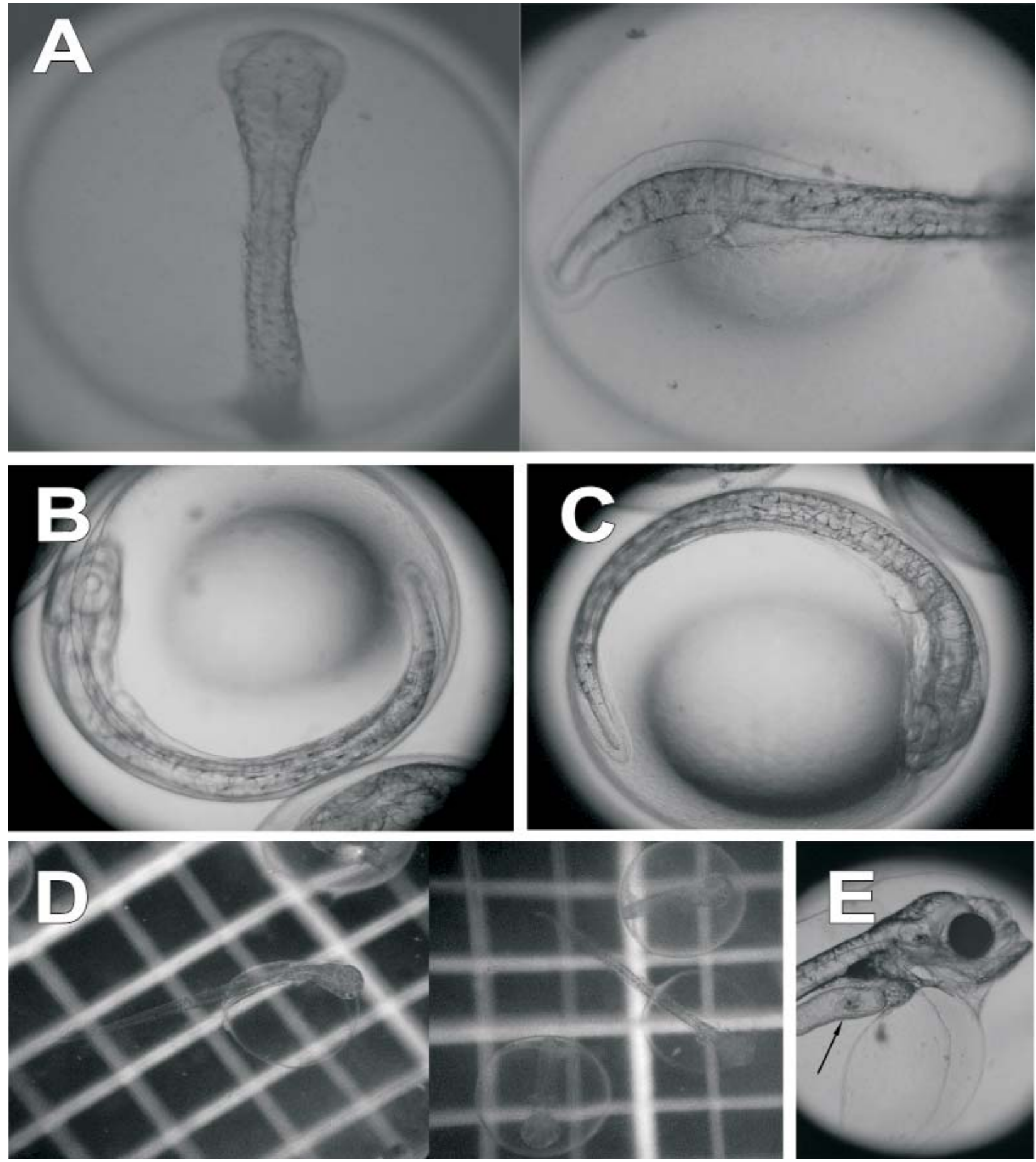

Fig. 3. Eggs and larvae of cod, Gadus morhua: $176 \mathrm{~h}$ after fertilization - the primordial fin folds are visible (A); $207 \mathrm{~h}$ after fertilization - contractions of the heart muscle and first embryo movements in the egg are clearly visible (B); $222 \mathrm{~h}$ after fertilization — the embryos are moving very actively (C); $236 \mathrm{~h}$ after fertilization — hatching begins (D); begin exogenous feeding before the yolk sac is fully resorbed; Rotifer in the digestive tract (arrow) of the feeding cod larva $(\mathbf{E})$ 
(WKDRCS), 9-12 May 2006, St. John's, Canada. ICES CM 2006/OCC 12: 1-155.

Anonymous 2015. Report of the Benchmark Workshop on Baltic Cod Stocks (WKBALTCOD), 2-6 March 2015, Rostock, Germany. ICES CM 2015/ACOM:35.

Brander K. (ed.) 2005. Spawning and life history information for North Atlantic cod stocks. ICES Cooperative Research Report No. 274.

Ellertsen B., Moksness E., Solemdal P., Tilseth S., Westgård T., Øiestad V. 1981. Growth and survival of cod larvae in an enclosure. Experiments and a mathematical model. Rapports et procès-verbaux des réunions du Conseil International pour l'exploration de la mer 178: 45-57.

Formicki K., Szulc J., Tański A., Korzelecka-Orkisz A., Witkowski A., Kwiatkowski P. 2013. The effect of static magnetic field on Danube huchen, Hucho hucho (L.) sperm motility parameters. Archives of Polish Fisheries 21 (3): 189-197.

DOI: $10.2478 /$ aopf-2013-0016

Garrod D.J., Schumacher A. 1994. North Atlantic cod: The broad canvas. ICES Marine Science Symposia 198: $59-76$.

Grauman G.B. 1973. Investigations of factors influencing fluctuations in abundance of Baltic cod. Rapports et procès-verbaux des réunions du Conseil International pour l'exploration de la mer 164: 73-76.

Hinrichsen H., Lehmann A., Möllmann C., Schmidt J. 2003. Dependency of larval fish survival on retention/dispersion in food limited environments: The Baltic Sea as a case study. Fisheries Oceanography 12 (4-5): 425-433.

DOI: $10.1046 /$ j.1365-2419.2003.00246.x

Horbowy J. 2009. Dorsz bałtycki - dynamika stada na tle warunków środowiska i zarządzania zasobami. [Baltic cod-stock dynamics in relation to the environmental conditions and resource management.] Pp. 271-282. In: Heese T., Piocha S., (eds.) Ekonomiczne, społeczne i prawnewyzwaniapaństwamorskiegowUniiEuropejskiej. [Economic, social, and legal challenges for a coastal nation of the European Union.] Środkowopomorska Rada Naczelna Organizacji Technicznej w Koszalinie, Poland. [In Polish.]

Köster F.W., Möllmann C. 2000. Trophodynamic control by clupeid predators on recruitment success in Baltic cod? ICES Journal of Marine Science 57 (2): 310-323. DOI: $10.1006 /$ jmsc. 1999.0528

Köster F.W., Möllmann C., Hinrichsen H.-H., Wieland K., Tomkiewicz J., Kraus G., Voss R., Makarchouk A., MacKenzie B.R., St. John M.A., Schnack D., Rohlf N., Linkowski T., Beyer J.E. 2005. Baltic cod recruitment-The impact of climate variability on key processes. ICES Journal of Marine Science 62 (7): 1408-1425.

DOI: 10.1016/j.icesjms.2005.05.004

Köster F.W., Neuenfeldt S., Möllmann C., Vinther M., St. John M.A., Tomkiewicz J., Voss R., Kraus G., Schnack D. 2003. Fish stock development in the Central Baltic Sea (1976-2000) in relation to variability in the physical environment. ICES Marine Science Symposia 219: 294-306.

Köster F.W., Schnack D. 1994. The role of predation on early life stages of cod in the Baltic. Dana 10: 179-201.

Laevastu T. 1965. Manual of methods in fisheries biology. FAO Manuals in Fisheries Science No. 1.

Lear W.H. 1998. History of fisheries in the northwest Atlantic. The 500-year perspective. Journal of Northwest Atlantic Fishery Science 23: 41-73.

Lindegren M., Möllmann C., Nielsen A., Stenseth N.C. 2009. Preventing the collapse of the Baltic cod stock through an ecosystem-based management approach. Proceedings of the National Academy of Sciences 106 (34): 14722-14727.

DOI: $10.1073 /$ pnas.0906620106

Meier H.E.M., Kauker F. 2003. Modeling decadal variability of the Baltic Sea: 2. Role of freshwater inflow and large-scale atmospheric circulation for salinity. Journal of Geophysical Research 108 (C11): 3368. DOI: 10.1029/2003JC001799

Mohrholz V., Naumann M., Nausch G., Krüger S., Gräwe U. 2015. Fresh oxygen for the Baltic SeaAn exceptional saline inflow after a decade of stagnation. Journal of Marine Systems 148: 152-166. DOI: $10.1016 /$ j.jmarsys.2015.03.005

Myers R.A., Hutchings J.A., Barrowman N.J. 1996. Hypotheses for the decline of cod in the North Atlantic. Marine Ecology Progress Series 138: 293-308.

Neuenfeldt S., Köster F.W. 2000. Trophodynamic control on recruitment success in Baltic cod: The influence of cannibalism. ICES Journal of Marine Science 57 (2): 300-309.

DOI: $10.1006 /$ jmsc. 2000.0647

Nissling A. 2004. Effects of temperature on egg and larval survival of cod (Gadus morhua) and sprat (Sprattus sprattus) in the Baltic Sea-Implications for stock development. Hydrobiologia 514 (1): 115-123. DOI: 10.1023/B:hydr.0000018212.88053.aa

Nissling A., Kryvi H., Vallin L. 1994. Variation in egg buoyancy of Baltic cod Gadus morhua and its implications for egg survival in prevailing conditions in the Baltic Sea. Marine Ecology Progress Series 110: 67-74.

Nissling A., Westin L. 1991. Egg buoyancy of Baltic cod (Gadus morhua) and its implications for cod stock fluctuations in the Baltic. Marine Biology 111 (1): 33-35.

DOI: $10.1007 / \mathrm{BF} 01986342$

Radtke K. 2003. Evaluation of the exploitation of eastern Baltic cod (Gadus morhua callarias L.) stock in 1976-1997. ICES Journal of Marine Science 60 (5): 1114-1122. DOI: $10.1016 / \mathrm{S} 1054-3139(03) 00094-8$

Rosenthal H., Hilge V. 2006. Aquaculture in the Baltic Sea area-A concept for joint research of Baltic Sea abutters. Informationen aus der Fischereiforschung $\mathbf{5 3}$ (1): 74-79.

DOI: $10.3220 / \operatorname{Infn} 53 \_74-79 \_2006$ 
Støttrup J.G., Overton J.L., Paulsen H., Möllmann Westin L., Nissling A. 1991. Effects of salinity on C., Tomkiewicz J., Pedersen P.B., Lauesen P. 2008. Rationale for restocking the eastern Baltic cod stock. Reviews in Fisheries Science 16 (1-3): 58-64.

DOI: $10.1080 / 10641260701678231$

Thompson B.M., Riley J.D. 1981. Egg and larval development studies in the North Sea cod (Gadus morhua L.). Rapports et procès-verbaux des réunions du Conseil International pour l'exploration de la mer 178: 553-559.

Uzars D., Plikshs M. 2000. Cod (Gadus morhua L.) cannibalism in the central Baltic: Interannual variability and influence of recruit abundance and distribution. ICES Journal of Marine Science 57 (2): 324-329.

DOI: $10.1006 /$ jmsc. 1999.0527

Vallin L., Nissling A. 2000. Maternal effects on egg size and egg buoyancy of Baltic cod, Gadus morhua; Implications for stock structure effects on recruitment. spermatozoa motility, percentage of fertilized eggs and egg development of Baltic cod (Gadus morhua), and implications for cod stock fluctuations in the Baltic. Marine Biology 108 (1): 5-9. DOI: $10.1007 / \mathrm{BF} 01313465$

Wieland K., Jarre-Teichmann A., Horbowa K. 2000. Changes in the timing of spawning of Baltic cod: Possible causes and implications for recruitment. ICES Journal of Marine Science 57 (2): 452-464. DOI: $10.1006 /$ jmsc. 1999.0522

Wieland K., Waller U., Schnack D. 1994. Development of Baltic cod eggs at different levels of temperature and oxygen content. Dana 10: 163-177.

Received: 29 October 2015

Accepted: 24 September 2016 Fisheries Research 49: 21-37. 